Article

\title{
Health and Establishment of Highway Plantings in Florida (United States)
}

\author{
Seth A. Blair 1, Andrew K. Koeser 1,*, Lara A. Roman 2, Gary W. Knox ${ }^{3}$, Mack Thetford 4 \\ 1 Department of Environmental Horticulture, CLCE, IFAS, University of Florida - Gulf Coast Research and \\ Education Center, 14625 County Road 672, Wimauma, FL 33598, United States; s.blair@ufl.edu, akoeser@ufl.edu* \\ 2 Philadelphia Field Station, USDA Forest Service, 100 N 20 th St., Suite 205, Philadelphia, PA 19103, United States; \\ lroman@fs.fed.us \\ 3 Department of Environmental Horticulture, IFAS, University of Florida - North Florida Research and Education \\ Center, 155 Research Road, Quincy, FL 32351, United States; gwknox@ufl.edu \\ 4 Department of Environmental Horticulture, IFAS, University of Florida - West Florida Research and Education \\ Center, 5988 Highway 90, Milton, FL 32583, United States; thetford@ufl.edu \\ * Correspondence: akoeser@ufl.edu; Tel.: +1-813-419-6589
}

\begin{abstract}
Urban tree planting initiatives can experience high levels of mortality during establishment years. Mortality tied to the stresses of transplanting can be partially negated or exacerbated depending on the species selected, nursery materials used, site conditions present, and management practices employed. Past research has quantified post-planting survival, health, and growth. However, varying climates, species, land use types, and management practices warrant additional region-specific research. The purpose of this study is to assess the success of plantings along Florida highways and identify species, site, and management factors related to tree and palm health and establishment. Results show high annual establishment survival (98.5\%) across 21 planting projects ranging from 9 to 58 months after installation, $(\mathrm{n}=2711)$. For transplanted palms, the presence of on-site irrigation significantly improved establishment from $96.2 \%$ to $99.4 \%$. No establishment differences were detected with regard to irrigation treatment for small-stature trees, shade trees, and conifers. Additionally, there were significant differences in tree health response among tree groups given species, management, and site factors.
\end{abstract}

Keywords: Highway Beautification; Transplant Shock; Transportation; Tree Establishment; Tree Health; Urban Forestry

\section{Introduction}

Urban tree growth and longevity has gained greater attention from researchers and practitioners in recent years [1-6], including those looking to increase long-term ecosystem services through planting initiatives $[1,7,8]$. In addition to documented benefits like improved human health [9], increased tourism [10], building energy conservation [11], and storm water management [12], urban trees provide transportation corridor-specific benefits such as improved driver mentality [13], enhanced roadway definition [14], and slowed asphalt degradation through shading [15].

In planting trees to increase these and other benefits, the first years after installation are often noted as the most difficult time of a tree's life [16,17]. Mortality during this establishment phase not only undermines future economic benefits [8], but can, in cases of extremely low survivorship, cause environmental harm when considering the material and energy inputs associated with nursery operations, installation, and maintenance [18]. To ensure urban plantings function as intended, factors 
related to post-planting mortality must be identified regionally, within specific land use types, and mitigated through best management practices.

\subsection{Factors that influence planting success}

Past research indicates that the survival or death of a newly-planted tree can be influenced by a range of factors. Vogt et al., [6] noted four distinct categories that helped predict tree mortality in urban environments: (1) tree-related factors, (2) environment-related factors, (3) management-related factors, or (4) community-related factors.

Tree-related factors include species selection [4,16,19], species water requirements [20], size at planting [21], mature tree size [1,17,20,22], and tree age or time since planting [2,4,20]. Additionally, tree health assessed at a given point in time has been cited as a factor for predicting future mortality [23] and growth [24]. For example, poor condition ratings during initial inventories correlated with tree mortality in follow-up inventories $[17,19]$. This indicates the usefulness of tree health metrics in urban forest management.

Environment-related factors include a range of conditions related to the climate, soil conditions, and land use of a site. Regarding land use, transportation corridors can be difficult sites for tree survival, with $20.2 \%$ average annual mortality reported (compared to an overall average mortality of $6.6 \%$ ) in a study from Baltimore, Maryland [25]. Similarly, Lu et al., [4] found that median trees planted in New York City, New York demonstrated only 53.1\% survival for trees ranging 3-9 years since planting. Mortality has been found to be positively correlated with increased traffic intensity and speed limits [4,26], but not all studies support that finding [6]. In a Florida tree establishment study, highway median tree growth was similar to that of parks and parking lot site types, while street trees demonstrated lower growth in two of three tested species [2].

Beyond land use, urban soil conditions can have a significant impact on tree survival, growth, and health [27,28]. In an extreme case of low roadside planting survival, Jim [29] attributed high first year mortality of trees $(95 \%)$ and palms $(63 \%)$ to poor soil conditions that included drainage, structure, $\mathrm{pH}$, salinity, and elemental toxicities. In roadside environments, underlying and adjacent soils are typically modified to support load [30]. These modified soils are highly compacted and low in organic material [31], reducing soil structure and aggregates suitable for tree growth [32]. Soil compaction limits root growth and root penetration into surrounding soil [33,34]. In addition to altered soil structure, high alkalinity (especially near concrete roadways) ultimately limits nutrient availability and uptake [35]. Heavy metals and other contaminants from traffic exist in roadside soils but are unlikely to reach toxicity levels that effect plant growth [35] and health ([36].

Florida soils are generally sandy-textured, which can limit water and nutrient holding capacity [37]. Combined with highway interchange slopes and embankments, runoff can increase and infiltration can be reduced. Without proper irrigation (and berms surrounding the transplanted rootball), trees may experience chronic drought conditions - especially during the winter dry period in peninsular Florida. Other site-related factors beyond soil include climate [2], microclimate [23,38], and crown light exposure. Vogt et al., [6] did not find crown light exposure to be a significant predictor of tree survival; however, Roman et al., [39] noted that high levels of sunlight exposure paired with irrigation cessation resulted in increased tree mortality for trees planted along a highway in California.

Management-related factors that can influence tree performance include, among other things, the contractor hired [40] and monitoring program employed [41]. Regarding new plantings, nursery cultivation practices [2,26,42], the presence of quality assurances/standards for nursery stock [2,39], proper handling of plant materials $[43,44]$, planting season selection $[1,2,6,16,20]$, and planting depth can impact survival $[45,46]$. After planting, management factors that influence tree performance include irrigation [47,48,2,6,39], staking care [40,49], mulching [48,50], and site mowing practices [51,52]. 
Roman et al., [39] reported a case study in California where high establishment survival (96.3\% over six years) was observed along highway sound walls. The authors attributed this to regionally-appropriate species selection, as well as planting and stewardship practices that included continuous monitoring and maintenance by trained volunteers and youth interns. Use of high quality nursery stock, on-site irrigation, mulching, weed removal, and staking as needed were other indicators of a high level of care received. The primary cause of mortality in this case study, as well as a study by Foster and Blaine [40], was vehicular strikes.

Multiple research efforts have explored relationships between community-related factors and tree survival and growth. Those factors include housing stability [20], property value [1], homeownership [6,53], volunteer commitment [54], and unemployment [53] with planting program success. More recently, Limoges et al. [55] did not find significance between socioeconomic factors and tree growth. Most of the aforementioned citations involved street or yard trees that were planted and/or maintained by residents and/or volunteers. The extent to which community factors impact planting programs which are planned, installed, and maintained by professionally trained, well-funded organizations is unknown.

\subsection{Health and establishment of palms}

While urban tree growth and longevity research is an active area of inquiry, most studies focus on trees in temperate climates [56]. As such, palms have been researched less than other woody plants. The relatively small body of research that examines factors of palm establishment in both landscape and nursery settings is summarized in Table 1. For species like Sabal palmetto where roots die back to the trunk when severed for harvesting, removing all of the living fronds before transplant can improve survival from $64 \%$ to $95 \%$ by lessening transpiration until new roots are regenerated (Table 1) [57]. Most palm species; however, regrow roots from the point at which they are cut after digging. As such, pruning at transplanting may not be necessary to maintain a root/shoot balance for these species during the establishment phase [58]. However, Broschat [58] demonstrated that recently transplanted Phoenix roebelenii, only benefitted from pruning when exposed to soil water stress. In general, benefits associated with frond removal (and tying) are variable and species specific [59].

Planting depth of palms is also a factor that can influence survival [60]. Hodel et al., [61] found transplant season temperature and rootball size to be the most important factors related to establishment success for Washingtonia robusta, Phoenix reclinata, and Phoenix canariensis. However, Broschat [62] observed that planting season in southern Florida may not be important as warm temperatures allow for near year-round root and shoot elongation. Hosek and Roloff [63] assessed urban site factors (aboveground space and distance to roadway) but found weak or no correlation with palm health. 
Table 1. Factors associated with palm growth, health, and transplant success.

\begin{tabular}{|c|c|c|c|c|c|}
\hline Reference & Setting/ Location & $\begin{array}{l}\text { Time Since } \\
\text { Planting }\end{array}$ & Species & Factors ${ }^{\mathrm{z}}$ & Notes \\
\hline $\begin{array}{l}\text { Broschat and } \\
\text { Donselman [64] }\end{array}$ & $\begin{array}{l}\text { Field Nursery/ } \\
\text { Fort Lauderdale, FL }\end{array}$ & 7 months & P. roebelenii, C. elegans & Biological age $(\mathrm{G}+, \mathrm{S}+)$ & Immature plants $=100 \%$ mortality \\
\hline Broschat [57] & $\begin{array}{l}\text { Median/ } \\
\text { Miami, FL }\end{array}$ & 8 months & S. palmetto & $\begin{array}{l}\text { Transplanting without fronds } \\
\left(\mathrm{G}^{+}, \mathrm{S}+\right)\end{array}$ & G assessed by canopy size \\
\hline \multirow[t]{2}{*}{ Broschat [58] } & $\begin{array}{l}\text { Nursery } \\
\text { Fort Lauderdale, FL }\end{array}$ & 5 months & $\begin{array}{l}\text { P. roebelenii (water } \\
\text { stressed) }\end{array}$ & $\begin{array}{l}\text { Transplanting without fronds } \\
(\mathrm{G}+, \mathrm{S}+)\end{array}$ & $\begin{array}{l}\text { G assessed using root dry-weight } \\
\text { and live-frond count }\end{array}$ \\
\hline & & & $\begin{array}{l}\text { P. roebelenii (non-water } \\
\text { stressed) }\end{array}$ & Top-irrigation (H -) & $\begin{array}{l}\text { Leaf-tying showed no } \\
\text { improvements }\end{array}$ \\
\hline Broschat [60] & $\begin{array}{l}\text { Field nursery/ } \\
\text { Fort Lauderdale, FL }\end{array}$ & 15 months & P. roebelenii & $\begin{array}{l}\text { Transplanting depth below } \\
\text { original (G -, H -, S-) }\end{array}$ & $\begin{array}{l}\text { G assessed using frond count. } \mathrm{H} \\
\text { assessed using tissue analysis }\end{array}$ \\
\hline Hodel [61] & $\begin{array}{l}\text { Arboretum/ } \\
\text { Los Angeles, CA }\end{array}$ & 3 years & $\begin{array}{l}\text { W. robusta, } P \text {. reclinata, } \\
\text { P. canariensis }\end{array}$ & $\begin{array}{l}\text { Wet season planting }\left(G^{+}\right) \text {, } \\
\text { rootball size }\left(G+, S^{+}\right)\end{array}$ & $\mathrm{G}$ assessed using root biomass \\
\hline Broschat [62] & $\begin{array}{l}\text { Rhizotron/ } \\
\text { Fort Lauderdale, FL }\end{array}$ & 2 years & $\begin{array}{l}\text { R.regia, C. nucifera, S. } \\
\text { romanzoffiana }\end{array}$ & Air/soil temperature $(\mathrm{G}+)$ & $\begin{array}{l}\text { G assessed with root/shoot } \\
\text { elongation and frond count. }\end{array}$ \\
\hline Hodel [59] & $\begin{array}{l}\text { Field nursery/ } \\
\text { Borrego Springs, CA }\end{array}$ & 5 months & W. robusta & $\begin{array}{l}\text { Leaf removal/tie (no effect } \mathrm{G}, \mathrm{H} \text {, } \\
\text { or S) }\end{array}$ & $\begin{array}{l}\text { G assessed w/ new leaf count. H } \\
\text { assessed visually (color) }\end{array}$ \\
\hline Hosek and Roloff [63] & $\begin{array}{l}\text { Urban environments/ } \\
\text { Olhão, Portugal }\end{array}$ & Unknown & $\begin{array}{l}\text { C. humilis, } \\
\text { W. robusta, } \\
\text { P. canariensis }\end{array}$ & $\begin{array}{l}\text { Above ground space }(\mathrm{H}+) \text {, } \\
\text { Distance to road }(\mathrm{H}+)\end{array}$ & $\begin{array}{l}\text { Weak correlations but sig. Health } \\
\text { assessed visually. }\end{array}$ \\
\hline
\end{tabular}




\subsection{Project justification}

The Florida Department of Transportation's (FDOT) “Bold Initiative” invests \$40 million (USD) annually on highway beautification [65]. Trees and palms serve as a key element of installations along the most travelled corridors. As project size has been noted to influence tree survival [1], the scale of this program warrants further investigation from the perspective of establishment performance. This monitoring, if incorporated into adaptive management efforts, can enhance the program's success and help ensure its projected economic impacts materialize [65]. In addition to economics, successful establishment and long-term survival of these plantings has the potential to provide human health (e.g., traffic calming) and ecological services for decades to come.

The goal of this research is to assess the establishment and health of FDOT plantings installed along Florida's highway system between 2011 and 2016. This work provides insight into tree-specific responses given varying site conditions and management techniques, which may help to guide appropriate management strategies and work specifications. Examining roadside trees in a so far under-researched region of the United States provides valuable information in the broader subject of tree growth and longevity research. In addition, the plantings assessed include a high percentage of palms (51.6\%), which are often absent from similar works published in the past.

\section{Materials and Methods}

Between June 26, 2017 and October 12, 2017, twenty-one roadside tree planting projects were sampled across seven (of eight) FDOT districts (Figure 1). District 6 (Miami), was excluded from inventory given the timing of the experiment and tree losses associated with Hurricane Irma [66]. Also excluded from data collection were Phoenix spp. due to the prevalence of lethal bronzing (formally Texas Phoenix palm decline or TPPD) in Florida, a phytoplasma pathogen that has been associated with catastrophic losses [67]. These exclusions allow analyses of mortality and health in more typical circumstances, absent catastrophic loss [68]. Within each district, planting project areas were randomly chosen from those installed between July 2012 and October 2015. Given the scale of the FDOT planting initiatives visited (where individual installations could have several hundred trees planted along every side of a particular highway interchange or FDOT property), one contiguous section of an interchange/site was selected at random for inventory. 


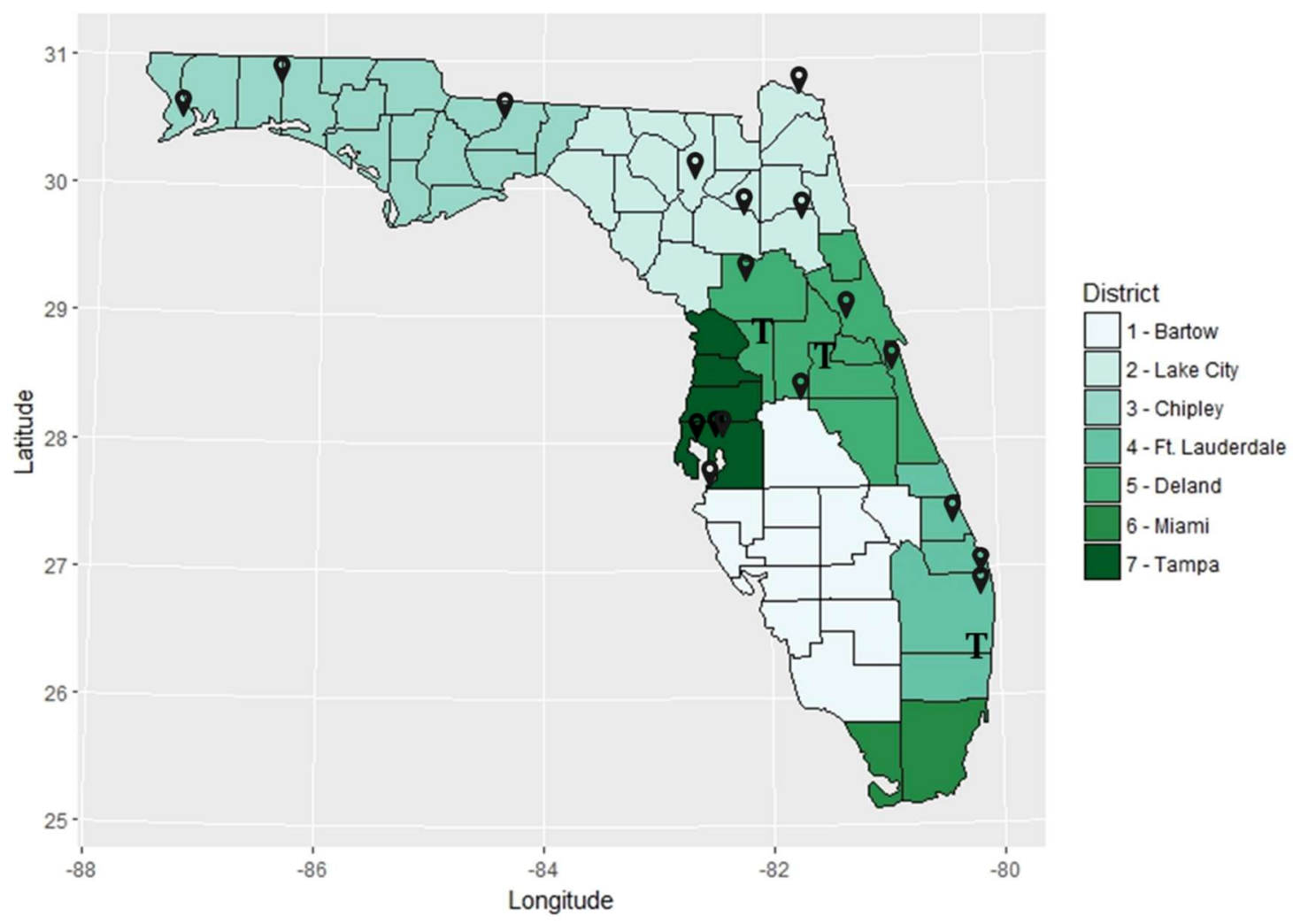

Figure 1. Florida Department of Transportation District Map (United States) with marked locations of planting projects sampled in this study. Turnpike District projects denoted with " $\mathrm{T}$ ".

All trees were installed by professional contract labor. FDOT favors the installation of container grown shade trees, small-stature trees, and conifers while palms are generally field-grown. Contractors were responsible for the planting and maintenance of projects for a specified time after planting (12 or 24 months, dependent upon contract specifications), known as the "establishment" phase. This phase began at the completion of the installation process. During the establishment phase, monthly inspections were made by FDOT personnel or subcontractors to ensure all trees were alive and at the highest grade according to the Florida Grades and Standards for Nursery Plants [68]. If those criteria were not met and uncorrectable, the contractor was notified to replace the tree with the same size/species and would be charged for each day the tree was not replaced, at no cost to FDOT. Contracts specified irrigation, fertilization, staking, and mulching but details varied by planting project. For example, some contracts specified that staking and bracing material be removed at the end of the first year of establishment, while others specified removal at the end of the second year. Within a planting project, some trees received drip irrigation (1,285 trees) while others were irrigated by truck or possibly non-irrigated (1,241 trees), dependent upon vehicular access and access to an irrigation source.

After final inspection of the establishment phase, the planting project maintenance responsibility was passed on to the FDOT Office of Maintenance or, in some instances, the project was turned over the surrounding municipality. In either case, FDOT regularly inspected landscape areas to assess survival and tree pruning needs.

For this study, establishment is defined as the proportion of trees alive compared to the number of trees encountered at the time of sampling, in contrast with numerous other methods to assess establishment [70]. Standing dead trees, stumps, and missing trees were all included when assessing trees 
that failed to fully establish in the landscape. Trees that appeared to be replacements were identified using visual cues that distinguished the tree from others in the planting project such as new mulch, new staking material, recently pruned canopy on palms, flagging tape, or different bark texture. However, true replacement status could not be confirmed.

Establishment and health were evaluated relative to a range of tree-, site-, and maintenance-related factors (Table 2). Health was rated using the method outlined by Bond [71] - classifying growth, opacity, ratio, quality, and vitality into $20 \%$ scoring classes. Among the site-related predictor variables assessed in this study were those detailed by Scharenbroch et al., [72] in their creation of the Rapid Urban Site Index (RUSI). The index was modified for this study, though the following factors were replicated exactly as detailed: distance to infrastructure (INFR), estimated rooting area (ERA), soil texture (TXT), soil structure (STRC), surface (SURF), wet aggregate stability (WAS), crown light exposure (EXP), A-horizon depth (AHOR), and electrical conductivity (EC). Modifications were made to penetration (PEN), growing degree days (GDD), precipitation (PPT), soil organic matter (SOM), $\mathrm{pH}(\mathrm{pH})$, and traffic (TRAF) factors and are listed in Table 3. In general, changes to the index were made to accommodate available equipment or to account for regional differences (Table 3).

Penetration (PEN) was measured using a soil cone penetrometer (Soil Compaction Tester, DickeyJohn Corporation, Auburn, Illinois, United States) $15.3 \mathrm{~cm}$ below ground at the outer periphery of the root ball. Two measurements were made per tree and the average readings were recorded. Additionally, percent slope was measured using a digital level (THD9407, Husky, Atlanta, Georgia, United States) on two sides of the tree (in line with the predominant slope) and averaged. The RUSI factors TRAF, INFR, ERA, SURF, and EXP were also recorded for each tree. Several RUSI variables (i.e., TXT, STRC, pH, EC, $\mathrm{OM}, \mathrm{AHOR}$, and WAS), were assessed for groups of trees planted in zones of similar soil characteristics that were stratified by visual cues (e.g. ground vegetation, slope, distance to hardscape, etc.,) within a given planting area. Within each stratified zone, ten samples were collected with a soil core and used to create an aggregate soil sample. Finally, the climatic ratings PPT and GDD were assessed at the site level (i.e., all trees at a given location had the same rating). 
Table 2. Overview of variables used in Florida Department of Transportation roadside tree planting analyses.

\begin{tabular}{|c|c|c|c|c|}
\hline Variable & Description & Type & $\begin{array}{l}\text { Collection } \\
\text { Levelx }\end{array}$ & Source \\
\hline \multicolumn{5}{|l|}{$\underline{\text { Response }}$} \\
\hline alive $(0 / 1)$ & any living foliage, present & binary & tree & \\
\hline quality (0-5) & $\begin{array}{l}\% \text { upper canopy free of chlorosis, } \\
\text { necrosis, stunting }\end{array}$ & ordered & tree & Bond (2012) \\
\hline vitality (0-5) & \% upper canopy free of dieback & ordered & tree & Bond (2012) \\
\hline \multicolumn{5}{|l|}{ Explanatory } \\
\hline trunk damage $(0 / 1)$ & lawn care, stakes, other & binary & tree & \\
\hline root flare $(0 / 1)$ & visible without digging & binary & tree & \\
\hline tree type ${ }^{y}$ & small-stature, shade, conifer, palm & categorical & tree & \\
\hline planting season & wet/dry & categorical & project & $\begin{array}{l}\text { Misra and Mishra } \\
(2016)\end{array}$ \\
\hline years since planting & $\begin{array}{l}\text { since beginning of establishment } \\
\text { phase }\end{array}$ & numeric & project & \\
\hline slope & median of $5 \%$ increments & numeric & tree & \\
\hline irrigation $(0 / 1)$ & installed at tree & binary & tree & \\
\hline stake duration & $>$ or $<$ one year & categorical & tree & Koeser et al., (2014) \\
\hline RUSI Scores & see Table 3 & ordered & $\begin{array}{l}\text { tree/zone/p } \\
\text { roject }\end{array}$ & $\begin{array}{l}\text { Scharenbroch et al., } \\
(2017)\end{array}$ \\
\hline
\end{tabular}

"Collection level indicates the location within a planting project data was collected, where "tree" indicates an individual observation. Data collected within a "zone" or "project" was applied to each observation within that specified area.

y Small-stature $(<9.14 \mathrm{~m})$ and shade $(>9.14 \mathrm{~m})$ were designated by maximum heights at maturity. 
Table 3. Scoring functions and adaptations of Rapid Urban Site Index parameters [72] for use in Florida Department of Transportation roadside tree planting analyses.

\begin{tabular}{|c|c|c|c|c|c|c|}
\hline \multirow{2}{*}{ RUSI Parameter } & \multirow[b]{2}{*}{ Units } & \multirow{2}{*}{$\begin{array}{l}\text { Collection } \\
\text { Levelv }^{\text {v }}\end{array}$} & \multicolumn{4}{|c|}{ RUSI Score } \\
\hline & & & 0 & 1 & 2 & 3 \\
\hline INFR & $\mathrm{m}$ & tree & $<1$ & $1-5$ & $6-10$ & $>10$ \\
\hline TRAF & $\mathrm{n} / \mathrm{a}$ & $\mathrm{n} / \mathrm{a}$ & \multicolumn{4}{|c|}{ excluded due to lack of site variation } \\
\hline SURF & $\mathrm{n} / \mathrm{a}$ & tree & bare soil & patchy veg & thick veg & mulch \\
\hline PEN & lbs/sq in. & tree & $300+$ & $201-300$ & $101-200$ & $0-100$ \\
\hline STRCy & $\mathrm{n} / \mathrm{a}$ & zone & M, SG, PL & $\mathrm{ABK}$ & SBK & GR \\
\hline $\mathrm{TXT}^{\mathrm{z}}$ & $\mathrm{n} / \mathrm{a}$ & zone & $\begin{array}{l}\text { no soil; } \\
\mathrm{CF}>75 \%\end{array}$ & $\begin{array}{l}\text { S, SI, C; } \\
C F=50-75 \%\end{array}$ & $\begin{array}{l}\text { LS, SCL, } \\
\text { SICL, CL, } \\
\text { SC, SIC; } \\
\text { CF=25-49\% }\end{array}$ & $\begin{array}{l}\text { SL, SIL, L; } \\
\mathrm{CF}<25 \%\end{array}$ \\
\hline $\mathrm{pH}$ & $\mathrm{pH}$ & zone & $<4$ or $>9$ & $4-4.9$ or $8.1-9$ & $5-5.9$ or $6.6-8$ & $6-6.5$ \\
\hline $\mathrm{EC}$ & $\mu S \mathrm{~cm}^{-1}$ & zone & $\begin{array}{l}<50 \text { or } \\
>3,000\end{array}$ & $\begin{array}{l}50-100 \text { or } \\
2,001-3,000\end{array}$ & $\begin{array}{l}101-300 \text { or } \\
1,001-2,000\end{array}$ & 301 to 1,000 \\
\hline $\mathrm{SOM}^{\mathrm{x}}$ & $\% \mathrm{OM}$ & zone & $<1.08$ & $1.08-1.60$ & $1.60-2.17$ & $>2.17$ \\
\hline AHOR & $\mathrm{Cm}$ & zone & $<1$ & $1-5$ & $6-15$ & $>15$ \\
\hline ERA & $\mathrm{m}^{2}$ & tree & $<5$ & $5-25$ & $26-50$ & $>50$ \\
\hline WAS & $\%$ & zone & no aggregate & $\begin{array}{l}<50 \% \text { post } \\
\text { soak }\end{array}$ & $\begin{array}{l}<50 \% \text { post } \\
\text { swirl }\end{array}$ & $\begin{array}{l}>50 \% \text { post } \\
\text { swirl }\end{array}$ \\
\hline PPT wx & $\mathrm{mm} \bullet \mathrm{yr}^{-1}$ & project & $<1290$ & $1290-1372$ & $1372-1585$ & $>1585$ \\
\hline GDD $^{x}$ & $\begin{array}{l}\text { days, base } \\
50\end{array}$ & tree & $<6992$ & $6992-7663$ & $7663-8069$ & $>8069$ \\
\hline EXP & \# sides & tree & 0 & $1-2$ & $3-4$ & 5 \\
\hline
\end{tabular}

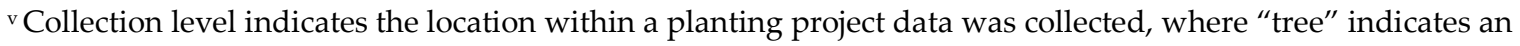
individual observation. Data collected within a "zone" or "project" was applied to each observation within that specified area.

${ }^{\mathrm{w}}$ scoring function unaffected by onsite irrigation

${ }^{x}$ scoring functions determined by breaking data into quantiles

y $\mathrm{M}=$ massive; $\mathrm{SG}=$ single grained; $\mathrm{PL}=$ platy; $\mathrm{ABK}=$ angular blocky; $\mathrm{SBK}=$ subangular blocky; $\mathrm{GR}=$ granular.

${ }^{\text {z }} \mathrm{CF}=$ coarse fragments; $\mathrm{C}=$ clay; $\mathrm{S}=$ sand; $\mathrm{S}=$ silt; $\mathrm{SIC}=$ silty clay; $\mathrm{SICL}=$ silty clay loam; $\mathrm{CL}$,=clay loam; $\mathrm{SC}=$ sandy clay; $\mathrm{SIL}=$ silt loam; $\mathrm{L}=$ loam; $\mathrm{SCL}=$ sandy clay loam; $\mathrm{SL}=$ sandy loam; $\mathrm{LS}=$ loamy sand.

Trees were classified and analyzed by tree type (shade, small-stature, conifer, and palm). Shade trees are those species that reach at least 9.14 meters (30 feet) at maturity while small-stature trees do not reach that threshold. Species with fewer than twenty observations were excluded from establishment and health analyses. Within tree type, species that did not experience any mortality (i.e. $0 \%$ missing, stumps, or standing dead) were excluded from establishment analysis. Given regional differences across Florida, planting season was determined based on the project location's wet season onset and demise observation 
dates [73]. Potential replacement trees were included in all analyses. All statistical analysis was performed using $R$ version 3.3.2 [74]. Attempts at modeling establishment success using logistic regression were unsuccessful given the high success rate (some cases had $100 \%$ establishment). Attempts to rectify the issue by reducing predictor variables failed. Therefore, the prop.test() function in $\mathrm{R}$ was utilized to test the null hypothesis that probabilities of tree establishment were not different when considering different treatments for on-site irrigation (i.e., present vs absent) which uses Pearson's chisquare test. An experiment-wise error rate was controlled for using a Holm adjustment [75].

Prior to analysis, health ratings were normalized based on the mode rating observed within each species [71]. Differences in health were normalized as deviations from the most common rating for each species (Table 4). Of the five health ratings detailed by Bond [71], quality and vitality were the most widely used among the species assessed and are reported in the results below. These two health responses were fit against the predictors noted in Table 2 using ordinal logistic regression. Modeling was conducted using the polr() function from the MASS package in R [76]. Full models were simplified to the final models reported below by removing non-significant predictors in a one-at-a-time manner and assessing whether the fit differed between the original and reduced model using the anova() function in $\mathrm{R}$ [77].

Table 4. Normalized health rating descriptions

\begin{tabular}{ll}
\hline Health Rating & Description \\
\hline Dead & Dead, missing, or removed observation \\
Critical & 3 or more deviations below the new normalized value \\
Poor & 2 deviations below the new normalized value \\
Fair & 1 deviation below the new normalized value \\
Normal & 0 deviations below the new normalized value \\
Excellent & 1 deviation above the new normalized value \\
\hline
\end{tabular}

Due to the importance of maintenance practices in urban tree planting initiatives, a binomial logistic regression was used to test the effects of mulching, staking, ERA (estimated rooting area), and years since planting on the presence or absence of lawn care damage on a tree. For all statistical tests, an alpha level of 0.05 was adopted as the threshold for significance.

\section{Results}

\subsection{Tree Establishment}

Based on installation records, the time since installation for the sampled projects ranged from 9-58 months. The average project age was 30 months. A total of 2711 trees were located and assessed. Of the trees sampled, $51.5 \%$ were palms, $18.4 \%$ were small-stature trees, $17.6 \%$ were shade trees, and $12.4 \%$ were coniferous trees (Appendix A).

When examining establishment, all tree groups had higher establishment success when permanent irrigation was present; however, the impacts were only statistically significant for palms $(\mathrm{P}=0.006)$ (Table 5). Within the palms, the most common species, S. palmetto establishment decreased from $99.4 \%$ to $95.8 \%$ when planted on non-irrigated sites $(\mathrm{P}=0.006)$. Non-irrigated $W$. robusta had a similar establishment $(95.3 \%)$ to non-irrigated S. palmetto $(95.8 \%)$, though the former species was not located on irrigated sites in the projects visited. While overall establishment did not differ for the conifers between irrigated and non- 
irrigated sites $(\mathrm{P}=0.356)$, Pinus palustris had significantly higher establishment success when planted on sites with irrigation installed $(\mathrm{P}=0.015)$.

Table 5. Establishment success for trees planted on sites with irrigation installed and for trees planted on sites lacking installed irrigation.

\begin{tabular}{c|cc|cc|c}
\hline \multirow{2}{*}{ Group } & \multicolumn{2}{|c|}{ irrigated } & \multicolumn{2}{c|}{ non-irrigated } & P-value \\
& \% established & n & \% established & n & (Holm) \\
\hline Conifer & 98.3 & 115 & 95.1 & 102 & 0.356 \\
Palm & 99.4 & 601 & 96.1 & 625 & 0.006 \\
Shade & 100 & 155 & 96.1 & 26 & $\mathrm{n} / \mathrm{a}$ \\
Small-stature & 99.6 & 285 & 97.8 & 90 & 0.290 \\
\hline
\end{tabular}

\subsection{Tree Health}

Of the 2711 relocated trees, 2403 trees were visually rated for health using the methods outline by Bond [71]. In modeling tree-, site-, and maintenance-related factors associated with increased or decreased health ratings, odds ratios were calculated to quantify the likelihood of a rating change given a one-unit change in an ordinal predictor variable (e.g. RUSI pH score increasing by one) or the presence/absence of categorical variable (e.g., on-site irrigation). A summary of significant effects is given in Figure 2. Individual models for each of the health response variables separated by tree type are included in Appendix B.
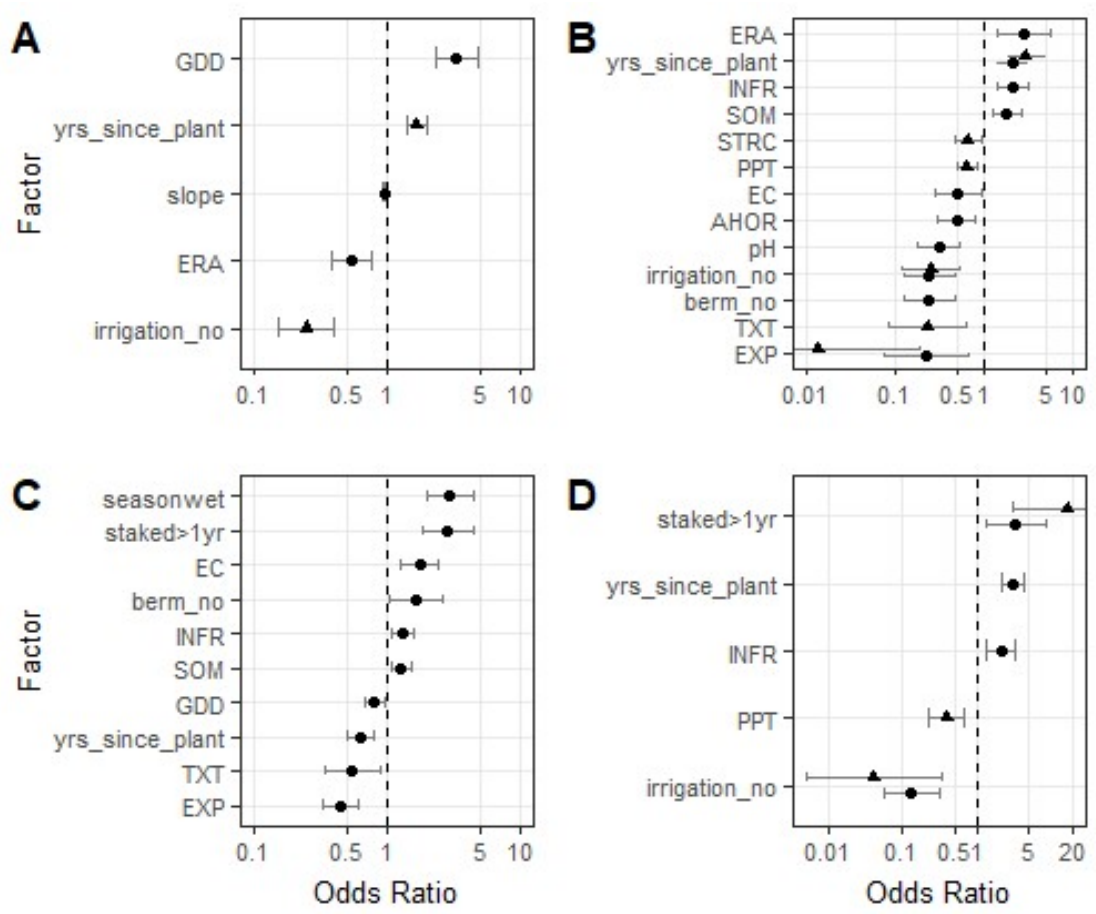

Model • quality * vitality

Figure 2. Odds ratios and corresponding $95 \%$ confidence intervals for significant factors $(\mathrm{P}=<0.05)$ from each of the seven final ordinal logistic regression models. Species groups are small-stature (A), shade (B), palm (C), and conifer (D). Rapid Urban Site Index factor abbreviations from the models include: A-horizon depth 
(AHOR), electrical conductivity (EC), estimated rooting area (ERA), crownlight exposure (EXP), growing degree days (GDD), distance to infrastructure (INFR), $\mathrm{pH}(\mathrm{pH})$, annual precipitation (PPT), soil organic matter (SOM), soil structure (STRC), and soil texture (TXT).

\subsubsection{Small-stature Trees}

In modelling quality ratings for small-stature trees, GDD (growing degree days) was the only significant factor to positively impact quality ratings with an odds ratio of 3.32 (P-value $=<0.0001$ ). As ERA (estimated rooting area) score increased, the likelihood of attaining a higher quality rating decreased $(P$-value $=0.0004)$. Finally, the small tree quality model was the only model to have slope as a significant factor, in that it had a negative, albeit slight, association with quality rating (odds ratio $=0.9575$; P-value < $0.0001)$.

For the final small-stature tree vitality model, species was again a significant predictor. Lagerstroemia spp. (odds ratio $=0.18, \mathrm{P}$-value $=0.0016$ ) had higher vitality ratings than Ilex X attenuate "Eagleston". In contrast, there was no difference in the vitality ratings for the Ligustrum japonicum as compared to the Ilex base-level (odds ratio $=0.43$; P-value $=0.1506$ ); Years since planting improved the likelihood of attaining a higher vitality rating (odds ratio $=1.67 ; \mathrm{P}$-value $<0.0001$ ) while the absence of on-site irrigation reduced the likelihood of attaining a higher vitality rating (odds ratio $=0.25 ; \mathrm{P}$-value $<0.0001$ ) (Figure 2).

\subsubsection{Shade Trees}

For shade trees, species had a significant impact on the quality health rating. In the most extreme comparison, Liquidambar styraciflua was 385 times more likely to receive a higher quality rating than the baseline of Delonix regia (P-value $<0.001$ ). Of the RUSI parameters, ERA had the highest odds ratio (odd ration $=2.82 ; \mathrm{P}$-value $=0.0028$ ) (Figure 2$)$. Other factors with positive impacts on shade tree quality included INFR (distance to infrastructure) and SOM (soil organic matter), with odds ratios of 2.10 (Pvalue $=0.0005)$ and $1.78(P$-value $=0.0022)$, respectively. An increase in RUSI scores for AHOR (A-horizon depth; odds ratio $=0.49 ; \mathrm{P}$-value $=0.0047)$, EC (electrical conductivity; odds ratio $=0.52 ; \mathrm{P}$-value $=0.0364)$, EXP (crown light exposure; odds ratio $=0.22 ; \mathrm{P}$-value $=0.0082$ ), and $\mathrm{pH}$ (odds ratio $=0.31 ; \mathrm{P}$-value $<$ 0.0001 ) were associated with a reduction in shade tree quality ratings (Figure 2.). Additionally, shade trees without on-site irrigation were less likely to attain a higher quality rating than those with irrigation installed (odds ratio $=0.24 ; \mathrm{P}$-value $<0.0001$ ). The same held true in the absence of berms (odds ratio $=$ 0.24; P-value $<0.0001$ ) (Figure 2).

For the final shade tree vitality model, L. styraciflua (odds ratio $=4.85 ; \mathrm{P}$-value $=0.0460$ ), Magnolia grandiflora (odds ratio $=21.05 ; \mathrm{P}$-value $<0.0001$ ), Peltophorum pterocarpum (odds ratio $=24.04 ; \mathrm{P}$-value $<$ 0.0001 ), and Swietenia mahagoni (odds ratio $=5.47 \times 107$; P-value $<0.0001$ ) had higher vitality ratings than the baseline of $D$. regia. Years since planting was also a significant predictor of vitality (odds ratio $=2.93$, P-value < 0.0001) (Figure 2). In the absence of on-site irrigation, shade trees were less likely to attain a higher vitality rating (odds ratio $=0.26$, P-value $=0.0004$ ). Counterintuitively, as PPT (annual precipitation) RUSI score increased, the likelihood of attaining a higher vitality rating decreased (odds ratio $=0.65 ;$ P-value $=0.0009$ ). Similar trends were noted with increased ratings for EXP (crown light exposure; odds ratio $=0.01 ; \mathrm{P}$-value $=0.0012)$, STRC (soil structure; odds ratio $=0.66 ; \mathrm{P}$-value $=0.0170$ ), and TXT (soil texture; odds ratio $=0.23 ; \mathrm{P}$-value $=0.0042)$ (Figure 2$)$.

\subsubsection{Conifers}

Both final vitality and quality models for conifer health ratings yielded similar results. P. palustris and Taxodium distichum were both outperformed by Pinus elliottii (Appendix 2). Similarly, absence of installed irrigation resulted in lower likelihoods of attaining higher quality (odds ratio $=0.13 ; \mathrm{P}$-value $=$ $<0.0001$ ) and vitality ratings (odds ratio $=0.04 ; \mathrm{P}$-value $=0.0026$ )(Figure 2 ). In contrast, being staked for 
greater than one year had the opposite effect - improving the likelihood of attaining a higher visual quality (odds ratio $=3.37 ; \mathrm{P}$-value $=0.0088)$ and vitality ratings (odds ratio $=16.72 ; \mathrm{P}$-value $=$ 0.0010)(Figure 2). INFR (distance to infrastructure) rating had a positive relationship with quality rating (odds ratio $=2.13 ;$ P-value $=0.0007$ ). As with the shade tree vitality model, PPT (annual precipitation) score was associated with a reduced likelihood of attaining a higher vitality rating (odds ratio $=0.40$; Pvalue $=0.0011)($ Figure 2$)$.

\subsubsection{Palms}

For the final palm quality model, again species was a significant predictor. When compared to the Wodyetia bifurcata base level, all other species were more likely to have higher quality ratings (min. odds ratio = 16.45; all P-values < 0.0001) (Appendix 2). Wet season plantings (odds ratio = 2.95; P-value < 0.0001 ), absence of berms (odds ratio $=1.65 ; \mathrm{P}$-value $=0.0293)$, staking for greater than one year (odds ratio $=$ 2.86; P-value < 0.0001), EC (electrical conductivity; odds ratio $=1.74 ; \mathrm{P}$-value $=0.0008$ ), INFR (distance to infrastructure; odds ratio $=1.30 ; \mathrm{P}$-value $=0.0077$ ), and SOM (soil organic matter; odds ratio $=1.27 ; \mathrm{P}$ value $=0.0051)$ scores improved the likelihood of attaining a higher quality rating (Figure 2 ). In contrast, increased years since planting (odds ratio $=0.63$; $\mathrm{P}$-value $=<0.0001$ ), EXP (crown light exposure; odds ratio $=0.44 ; \mathrm{P}$-value $=<0.0001$ ), GDD (growing degree days; odd ratio $=0.80, \mathrm{P}$-value $=0.0204$ ), and TXT (soil texture; odds ratio $=0.54 ; \mathrm{P}$-value $=0.0155$ ) were associated with lower quality ratings (Figure 2 ).

\subsection{Maintenance Practices}

Results from logistic regression show that both staking and mulching protect trees from the lawn care damage (Table 6) while a one unit score increase in ERA (estimated rooting area) makes a tree 2.24 times more likely to be damaged with lawn care equipment.

Table 6. Odds ratios and corresponding 95\% confidence intervals (calculated for the odds ratio) resulting from binary logistic regression. An odds ratio greater than 1 indicates an increased likelihood of a tree be damaged by lawncare equipment per one unit increase in the predictor.

\begin{tabular}{lllllll}
\hline Factor & Coefficient & SE & p-value & OR & CI low & CI high \\
\hline Mulched & -1.2336 & 0.2413 & 0.0000 & 0.2912 & 0.1815 & 0.4674 \\
Staked & -1.4842 & 0.5277 & 0.0049 & 0.2267 & 0.0806 & 0.6378 \\
yrs_since_planting & 0.1903 & 0.1179 & 0.1064 & 1.2096 & 0.9601 & 1.5240 \\
ERA $^{x}$ & 0.8053 & 0.2305 & 0.0005 & 2.2373 & 1.4240 & 3.5153 \\
\hline
\end{tabular}

xEstimated rooting area

\section{Discussion}

\subsection{Tree Establishment}

With establishment ranging from $97.3 \%$ (conifers) to $99.8 \%$ (shade tree) (Appendix A), the program studied has one of the highest success rates in the growth and longevity literature. However, it is important to note that these plantings do include replacement trees as part of the installation and maintenance contract. As such, we have taken care throughout this manuscript to describe planting success in terms of establishment in the landscape (as opposed to mortality). As replacement trees are included in our models, the most comparable study to this work is the assessment of Florida Forest Service funded planting initiatives conducted by Koeser et al., [2]. In this study of 26 planting projects $(n=2354)$, an establishment rate of $93.6 \%$ two to five years after planting was observed. 
This important caveat noted, our findings are in line with a recent case study documented by Roman et al., [39] who observed a 96.3\% establishment survival 6 years after planting for highway trees in East Palo Alto, California (United States). While key differences exist between these two planting programs (notably, the East Palo Alto location was maintained by volunteers and youth interns and the trees were not covered with a replacement policy) there were similarities in the care given related to nursery stock quality assurance, irrigation and mulch to maintain soil moisture, and the use of staking materials to support and protect recently-planted trees.

Establishment did not vary between irrigated and non-irrigated sites for shade, small-stature, and conifer tree groups (Table 5). A statistically significant differenced did exist for palms, however. This appeared to be driven by differences in establishment for S. palmetto (Appendix A). For this species, severed roots die back to the trunk during harvest, increasing the potential for post-planting water stress [57].

\subsection{Tree Health}

Although each of the seven health models developed for this study offered slightly different results given the rating and group assessed (Figure 2; Appendix B), certain themes arose in the data. Specifically, irrigation, years since planting, INFR (distance to infrastructure), EXP (crown light exposure), and stake duration were significant predictors of quality and/or vitality ratings that appeared in at least three models (Figure 2).

The absence of on-site irrigation repeatedly resulted in visual health reductions. This finding is supported by past research in Florida demonstrating higher survival and increased growth in recentlyinstalled trees under irrigation [78]. Counterintuitively, increases in PPT (annual precipitation) score had the opposite effect of on-site irrigation on shade tree vitality and conifer vitality ratings. It should be noted that PPT is a rather coarse metric for characterizing potentially complex weather patterns. Rains in Florida can be quite sporadic. The state can endure several months of drought and make up its year-todate rain deficit in a single rain event such as a tropical storm [79].

Also related to water availability is the construction of soil berms intended to help retain water near the rootball and improve infiltration, especially when slopes increase potential runoff. Berms improved shade tree quality but reduced palm quality. Further research investigating the effectiveness of berms in improving tree performance is warranted. Interestingly, increased EXP (crown light exposure) reduced ratings for palm quality, as well as, shade tree quality and vitality. In the RUSI system, increases in exposure are associated with higher (more beneficial) scores [72]. However, [39] attributed excessive sun exposure paired with irrigation cessation several years after planting as a potential factor of tree death in East Palo Alto, California. If trees were drought stressed in our study population, full sun exposure may have exacerbated these water-limiting conditions.

Another factor related to water management was planting season (i.e., wet versus dry). We found wet season plantings yielded higher quality ratings for palms. This relationship supports findings by Roman et al., [20] and previous palm-specific research that found wet and warm season plantings improve establishment [61,62]. Other tree types in this study were uninfluenced by season. Vogt et al., [6] acknowledges the existence of a complex relationship among planting season, watering strategy, and precipitation. Moreover, other researchers have had conflicting findings regarding planting season. In their assessment of Sacramento, California tree plantings, Ko et al., [1] noted less mortality for trees installed during the dry season.

Small-stature trees, shade trees, and conifers generally exhibited greater health with age (Figure 2). Vogt et al., [6] explained this when they noted that older plantings have had more time to experience losses associated with transplant shock. Once this attrition (or in our case, replacement) has weeded out poorer performing trees, what remains are healthier individuals. In contrast, palm health declined with 
age. Palms not adapted to Florida's sandy soils can develop nutrient deficiencies which would impact quality ratings. These deficiencies can take years to correct once visible [80]. While fertilization from the nursery may be enough to initially sustain a transplanted species, the absence of supplemental fertilization may manifest as deficiency symptoms as new fronds develop over time.

INFR (distance to infrastructure) showed up in three models and had a positive association with health, corroborating past findings by Koeser et al., [19], where expanding widths from sidewalk to curb improved tree condition, and research by Sanders and Grabosky [81], where tree growth increased in wider parking lot cut-outs. In contrast, ERA (estimated rooting area) yielded mixed results in our health analysis, after being the most strongly correlated-to-tree health variable in the RUSI model [72]. One possible explanation is that trees in this study are still in the younger stages of their life cycle, and rooting area may be less limiting at their current size [4]. Also, roots were rarely restricted by infrastructure on more than one side in our sample.

Staking longer than one year improved visual health ratings. For palms, Broschat et al., [82] recommends bracing materials be removed 6-8 months after planting, although retaining bracing materials will not girdle palm trunks as with broadleaf and coniferous trees. Although it was initially viewed that retaining stakes for more than one year may be an indicator of reduced care, contractual requirements in some cases call for two-year staking. Trees staked beyond that timeframe may have been under additional care resulting from late-establishment-phase replacements. Moreover, trees with staking materials had lower incidence of lawn mowing damage (see below). Regardless, these findings indicate that retaining stakes for more than one growing season may not cause harm if monitored and adjusted to prevent girdling.

\subsection{Tree Maintenance}

Several indicators of tree maintenance and stewardship were recorded to allow for comparison among other studies (Table 7). Past research has used visual cues related to care at-planting (e.g., planting depth) and post-planting (e.g., trunk protection with mulch, stakes, etc.) to assess differences in establishment and survival [20]. In assessing these FDOT plantings, we found evidence that follow-up maintenance practices were being followed at high rates compared to other assessments of early tree growth and longevity (Table 7). For example, Vogt et al., [6] found trunk damage on $47.4 \%$ of recently established trees (average age of 4.47 years after planting) (Table 7 ). In contrast, we found $8.1 \%$ of trees to have trunk damage (average age of 2.4 years after planting).

Similarly, lawn care damage in the FDOT plantings assessed was notably lower than reported in by Morgenroth et al., [51] in Christchurch, New Zealand. However, trees ranged from $3 \mathrm{~cm}$ to $253 \mathrm{~cm}$ in DBH in the aforementioned study, making it plausible that older (and larger) trees had more years to receive lawn care damage.

Within our sampled trees, we found measures of care in place which reduced the likelihood of injuries related to lawn care activities. For example, mulched trees were nearly three times less likely to have lawn care damage than non-mulched trees (Table 6). Similarly, staked trees were half has likely to shown signs of lawn care damage as trees without staking (Table 6). Less intuitively, we found that lawn care damage increased as estimated rooting area (ERA) scores increased. In talking with FDOT staff, they predicted this even before our analysis as contractors use larger equipment when trees are spaced farther apart. Large tractor-pulled brush mowing attachments are harder to maneuver around trees than the smaller zero-turn mowers used in close quarters.

Although trunk wounding can lead to long term issues with health and stability, the presence of trunk wounds was not a significant predictor in our health models. Percival and Smiley (2015) attribute timing, species-specific ability to compartmentalize decay, and extent of stem wounding to be a determinant of the tree response. As a simple yes or no predictor variable, our data on trunk damage did 
not capture variability in wounding intensity which may have limited our ability to detect differences in visual health ratings.

Comparisons can also be made regarding tree staking practices. In an assessment of 488 trees in Guelph, Ontario (Canada), Labrosse et al., [49], observed that 17\% of trees were girdled to some degree by staking materials. Prior to this study, Foster and Blaine [40], observed 81\% of Boston, Massachusetts (United States) street trees had been damaged by staking materials. In our assessment of FDOT initiatives, only $1 \%$ of trees showed visible damage from stabilization measures. While damage was minimal, a greater proportion of trees planted by FDOT were staked longer than one year (11.5\%) than was observed by Koeser et al., [2] in Florida Forest Service funded planting initiatives (2.5\%; Table 7). From a project stewardship perspective, Roman et al., [20] recommend the use of an overall combined maintenance rating in order to guide future tree maintenance. The FDOT currently conducts a multipoint inspection of its plantings, which may explain the care noted in Table 7.

Table 7. Summary of maintenance practices observed on FDOT planted trees in comparison with past observations of landscape trees in other studies.

\begin{tabular}{|c|c|c|c|}
\hline \multirow{2}{*}{$\begin{array}{l}\text { Maintenance } \\
\text { Factor }\end{array}$} & FDOT & Previous Work(s) & \multirow{2}{*}{ Citation } \\
\hline & $\%(n)$ & $\%(n)$ & \\
\hline \multirow{3}{*}{$\begin{array}{l}\text { Lawn care } \\
\text { damage }\end{array}$} & \multirow{3}{*}{$6 \%\left(1202^{z}\right)$} & $62.9 \%(1018)$ & Morgenroth et al., [51] \\
\hline & & $0.0 \%(568)$ & Roman et al., [39] ${ }^{\mathrm{w}}$ \\
\hline & & $7.2 \%(291)$ & Roman et al., [20] \\
\hline $\begin{array}{l}\text { Total trunk } \\
\text { damage }\end{array}$ & $8 \%\left(1202^{z}\right)$ & $47.4(656)$ & Vogt et al., [6] \\
\hline \multirow{3}{*}{ Staking damage } & \multirow{3}{*}{$1 \%\left(1202^{z}\right)$} & 50-84\% (unknown) & Foster and Blaine [40] \\
\hline & & $17 \%(488)$ & Labrosse et al., [49] \\
\hline & & $37.5 \%(291)$ & Roman et al., [20] \\
\hline Staking $>1$ year & $11.5 \%(2135)$ & $2.5 \%(2354)$ & Koeser et al., [2] \\
\hline \multirow{4}{*}{ Mulched } & \multirow{4}{*}{$76.5 \%$ (2491) } & $7.2 \%(13405)$ & Lu et al., [4] \\
\hline & & $100.0 \%(568)$ & Roman et al., [39] ${ }^{\mathrm{w}}$ \\
\hline & & $38.5 \%(291)$ & Roman et al., [20] \\
\hline & & $10.5 \%\left(658^{x}\right)$ & Vogt et al., [6] $]^{x}$ \\
\hline $\begin{array}{l}\text { Root flare } \\
\text { visible }\end{array}$ & $50.1 \%(2495)$ & $27.4 \%(658)$ & Vogt et al., [6] \\
\hline Girdling roots & $1.25 \%\left(1116^{z}\right)$ & $\mathrm{n} / \mathrm{a}$ & $\mathrm{n} / \mathrm{a}$ \\
\hline $\begin{array}{l}\text { Poor branch } \\
\text { structure }\end{array}$ & $3 \%\left(969^{z y}\right)$ & $\mathrm{n} / \mathrm{a}$ & $\mathrm{n} / \mathrm{a}$ \\
\hline \multicolumn{4}{|c|}{$\begin{array}{l}{ }^{\mathrm{z}} \text { palms excluded } \\
\text { y small-stature trees excluded } \\
\mathrm{x} \text { trees that were mulched properly } \\
\text { w data from East Palo Alto, California }\end{array}$} \\
\hline
\end{tabular}




\section{Conclusions and Recommendations}

This research investigated a multitude of factors to quantify how they relate to both establishment and health of recently installed trees along Florida transportation corridors. Overall, we found a high level of establishment success for these plantings. In looking at establishment success with regard to irrigation, the two methods of irrigation (e.g., water truck vs installed system) employed seemed equally effective for most of the tree types assessed. In particular, palms (specifically S. palmetto) appeared to benefit from a dedicated irrigation system.

In addition to high establishment rates, the FDOT "Bold Initiative" plantings assessed for this study yielded high visual health ratings, despite any site challenges associated with their proximity to roadways. While growth is often a measure of urban tree health, this work shows the potential of visual health ratings in assessing factors that influence tree performance - especially when initial size at planting is not known. Moreover, visual aesthetics are generally prioritized over growth once trees leave the nursery for the landscape. This work also demonstrates the potential of incorporating an urban site index to assess planting location suitability, although some counterintuitive findings signal for the need of collective, regional efforts to better define scoring functions for site factors. As such, the methods employed in this study are well suited for the gauging the effectiveness of past management efforts.

Author Contributions: Conceptualization, AKK and SAB; Data curation, SAB and AKK; Formal analysis, SAB and AKK; Funding acquisition, AKK; Investigation, SAB; Methodology, SAB, AKK, LAR, GWK and MT; Project administration, SAB and AKK; Resources, AKK; Software, SAB and AKK; Supervision, AKK, LAR, GWK and MT; Visualization, SAB; Writing - original draft, SAB; Writing - review \& editing, AKK, LAR, GWK and MT.

Acknowledgements: This work was funded by the Florida Department of Transportation under grant BDV31 977-75 "Clear Recovery Zone Vegetation Requirements, and Review of Current Tree Pruning and Maintenance Practices for Landscape, Urban and Rural Areas within the Right of Way." The opinions, findings and conclusions expressed in this publication are those of the author(s) and not necessarily those of the Florida Department of Transportation of the U.S. Department of Transportation. 


\section{Appendix A}

Table A1. Percent establishment of observed tree species planted along Florida roadsides from July 2012 -

October 2015.

\begin{tabular}{|c|c|c|c|c|}
\hline Tree Type & Species & Common name & $\mathbf{n}$ & Establishment (\%) \\
\hline \multirow{15}{*}{ Shade trees } & Acer rubrum & red maple & 10 & 100 \\
\hline & Carya glabra & pignut hickory & 3 & 100 \\
\hline & Chionanthus virginicus & fringe tree & 9 & 100 \\
\hline & Chorisia speciosa & silk-floss tree & 12 & 100 \\
\hline & Delonix regia & royal poinciana & 42 & 100 \\
\hline & Elaeocarpus decipiens & Japanese blueberry & 23 & 100 \\
\hline & Ilex $x$ attenuata & 'East Palatka' holly & 10 & 100 \\
\hline & Liquidambar styraciflua & sweetgum & 33 & 100 \\
\hline & Magnolia grandiflora & Southern magnolia & 115 & 100 \\
\hline & Peltophorum pterocarpum & yellow poinciana & 35 & 100 \\
\hline & Quercus virginiana & southern live oak & 159 & 99.4 \\
\hline & Senna surattensis & glossy shower & 4 & 100 \\
\hline & Swietenia mahagoni & mahagony & 23 & 100 \\
\hline & Ulmus alata & winged elm & 1 & 100 \\
\hline & Shade tree totals & & 479 & 99.8 \\
\hline \multirow{10}{*}{$\begin{array}{l}\text { Small-stature } \\
\text { trees }\end{array}$} & Cercis canadensis & eastern redbud & 19 & 100 \\
\hline & Coccoloba uvifera & sea grape & 20 & 100 \\
\hline & Ilex $x$ attenuata & ‘Eagelston' holly & 29 & 100 \\
\hline & Lagerstroemia spp. & crapemyrtle & 330 & 99.7 \\
\hline & Ligustrum japonicum & Japanese privet & 68 & 97.1 \\
\hline & Olea europaea & olive & 7 & 100 \\
\hline & Prunus umbellata & flatwoods plum & 12 & 100 \\
\hline & Tabebuia aurea & Caribbean trumpet & 3 & 100 \\
\hline & Tabebuia heptaphylla & pink trumpet tree & 11 & 100 \\
\hline & Small-stature tree totals & & 499 & 99.4 \\
\hline \multirow{7}{*}{ Conifers } & Juniperus virginiana & redcedar & 8 & 100 \\
\hline & Pinus elliottii & slash pine & 95 & 100 \\
\hline & Pinus palustris & longleaf pine & 110 & 95.5 \\
\hline & Pinus taeda & loblolly pine & 9 & 100 \\
\hline & Taxodium ascendens & pondcypress & 1 & 100 \\
\hline & Taxodium distichum & baldcypress & 112 & 97.3 \\
\hline & Conifer totals & & 335 & 97.3 \\
\hline \multirow{12}{*}{ Palms } & Archontophoenix alexandrae & Alexander palm & 32 & 96.9 \\
\hline & Bismarckia nobilis & Bismarck palm & 156 & 100 \\
\hline & Butia odorata & mule palm & 5 & 100 \\
\hline & Hyophorbe lagenicaulis & bottle palm & 19 & 100 \\
\hline & Livistionia chinensis & Chinese fan palm & 99 & 98.0 \\
\hline & Ptychosperma elegans & solitaire palm & 44 & 100 \\
\hline & Roystonea regia & royal palm & 104 & 100 \\
\hline & Sabal palmetto & sabal palm & 667 & 97.9 \\
\hline & Trachycarpus fortunei & windmill palm & 19 & 100 \\
\hline & Washingtonia robusta & Mexican fan palm & 232 & 95.3 \\
\hline & Wodyetia bifurcata & foxtail palm & 21 & 100 \\
\hline & Palm totals & & 1398 & 98.0 \\
\hline
\end{tabular}




\section{Appendix B}

Table B1. Final model and ordinal logistic regression results for shade tree quality. Data was collected along Florida Department of Transportation corridors as part of a statewide "Bold Landscaping Initiative."

\begin{tabular}{|c|c|c|c|c|c|c|}
\hline Factor & Coefficient & SE & P-value & OR & CL low & CL high \\
\hline Berm - no & -1.4231 & 0.3336 & $<0.0001$ & 0.2410 & 0.1253 & 0.4634 \\
\hline Irrigation - no & -1.4082 & 0.3466 & $<0.0001$ & 0.2446 & 0.1240 & 0.4825 \\
\hline $\begin{array}{l}\text { Years since } \\
\text { planting }\end{array}$ & 0.7326 & 0.1863 & 0.0001 & 2.0805 & 1.4439 & 2.9977 \\
\hline AHORy & -0.7154 & -0.2531 & 0.0047 & 0.4890 & 0.2978 & 0.8031 \\
\hline $\mathrm{EC}^{\mathrm{y}}$ & -0.6609 & -0.3158 & 0.0364 & 0.5164 & 0.2781 & 0.9589 \\
\hline ERA $^{y}$ & 1.0382 & 0.3472 & 0.0028 & 2.8242 & 1.4299 & 5.5779 \\
\hline EXPy & -1.4974 & 0.5662 & 0.0082 & 0.2237 & 0.0738 & 0.6786 \\
\hline INFRy & 0.7424 & 0.2121 & 0.0005 & 2.1009 & 1.3864 & 3.1837 \\
\hline $\mathrm{pH}^{\mathrm{y}}$ & -1.1679 & 0.2868 & $<0.0001$ & 0.3110 & 0.1773 & 0.5456 \\
\hline SOMy & 0.5782 & 0.1890 & 0.0022 & 1.7829 & 1.2310 & 2.5822 \\
\hline E. decipiens ${ }^{\mathrm{x}}$ & 3.5221 & 0.8682 & $<0.0001$ & 33.8554 & 6.1740 & 185.6470 \\
\hline L. styraciflua ${ }^{\mathrm{x}}$ & 5.9546 & 0.8364 & $<0.0001$ & 385.5352 & 74.8366 & 1986.1603 \\
\hline M. grandiflora ${ }^{\mathrm{x}}$ & 1.4140 & 0.5046 & 0.0051 & 4.1124 & 1.5297 & 11.0557 \\
\hline P. pterocarpum ${ }^{\mathrm{x}}$ & 1.2911 & 0.5420 & 0.0172 & 3.6369 & 1.2572 & 10.5213 \\
\hline Q. virginiana ${ }^{\mathrm{x}}$ & 2.2992 & 0.4938 & $<0.0001$ & 9.9661 & 3.7860 & 26.2338 \\
\hline S. mahagoni ${ }^{\mathrm{x}}$ & 2.9213 & 0.8551 & 0.0006 & 18.5648 & 3.4740 & 99.2078 \\
\hline
\end{tabular}

${ }^{x}$ For species comparisons, D. regia was used as the baseline. For example, M. grandiflora was 4.1 times more likely to have a higher quality rating when compared to D. regia baseline. yRapid Urban Site Index factors include A-horizon depth (AHOR), electrical conductivity (EC), estimated rooting area (ERA), crownlight exposure (EXP), distance to infrastructure (INFR), $\mathrm{pH}(\mathrm{pH})$, and soil organic matter (SOM).

Table B2. Final model and ordinal logistic regression results for shade tree vitality. Data was collected along Florida Department of Transportation corridors as part of a statewide "Bold Landscaping Initiative."

\begin{tabular}{|c|c|c|c|c|c|c|}
\hline Factor & Coefficient & SE & P-value & OR & CL low & CL high \\
\hline Irrigation - no & -1.3557 & 0.3837 & 0.0004 & 0.2578 & 0.1215 & 0.5468 \\
\hline $\begin{array}{l}\text { Years since } \\
\text { planting }\end{array}$ & 1.0734 & 0.2399 & $<0.0001$ & 2.9254 & 1.8280 & 4.6814 \\
\hline EXPy & -4.2947 & 1.3283 & 0.0012 & 0.0136 & 0.0010 & 0.1843 \\
\hline РPТу & -0.4334 & 0.1305 & 0.0009 & 0.6483 & 0.5020 & 0.8372 \\
\hline STRCy & -0.4154 & 0.1741 & 0.0170 & 0.6601 & 0.4692 & 0.9285 \\
\hline ТХТу & -1.4615 & 0.5112 & 0.0042 & 0.2319 & 0.0851 & 0.6315 \\
\hline E. decipiens ${ }^{\mathrm{x}}$ & -0.1652 & 0.6020 & 0.7838 & 0.8477 & 0.2605 & 2.7584 \\
\hline L. styracifluax & 1.5780 & 0.7909 & 0.0460 & 4.8455 & 1.0283 & 22.8317 \\
\hline M. grandiflora & 3.0471 & 0.5441 & $<0.0001$ & 21.0537 & 7.2468 & 61.1660 \\
\hline P. pterocarpum ${ }^{\mathrm{x}}$ & 3.1798 & 0.7273 & $<0.0001$ & 24.0420 & 5.7792 & 100.0180 \\
\hline Q. virginiana ${ }^{x}$ & 0.6310 & 0.3923 & 0.1078 & 1.8794 & 0.8711 & 4.0548 \\
\hline \multirow[t]{2}{*}{ S. mahagoni ${ }^{x}$} & 17.8176 & $<0.0001$ & $<0.0001$ & 54712190.30 & 54712036.33 & 54712344.27 \\
\hline & & & & 18 & 16 & 24 \\
\hline
\end{tabular}

${ }^{x}$ For species comparisons, D. regia was used as the baseline. For example, Q. virginiana was 1.87 times more likely to have a higher vitality rating when compared to D. regia baseline. yRapid Urban Site Index factors within the model include crownlight exposure (EXP), annual precipitation (PPT), soil structure (STRC), and soil texture (TXT). 
Table B3. Final model and ordinal logistic regression results for small-stature tree quality. Data was collected along Florida Department of Transportation corridors as part of a statewide "Bold Landscaping Initiative."

\begin{tabular}{lcccccc}
\hline Factor & Coefficient & SE & P-value & OR & CL low & CL high \\
\hline ERA $^{x}$ & -0.6061 & 0.1711 & 0.0004 & 0.5455 & 0.3901 & 0.7628 \\
GDD $^{x}$ & 1.2026 & 0.1852 & $<0.0001$ & 3.3288 & 2.3153 & 4.7858 \\
Slope & -0.0434 & 0.0090 & $<0.0001$ & 0.9575 & 0.9408 & 0.9745 \\
\hline
\end{tabular}

${ }^{\times}$Rapid Urban Site Index factors within the model include estimated rooting area (ERA) and growing degree days (GDD).

Table B4. Final model and ordinal logistic regression results for small-stature tree vitality. Data was collected along Florida Department of Transportation corridors as part of a statewide "Bold Landscaping Initiative."

\begin{tabular}{lcccccc}
\hline Factor & Coefficient & SE & P-value & OR & CL low & CL high \\
\hline Irrigation - no & -1.3960 & 0.2415 & $<0.0001$ & 0.2476 & 0.1542 & 0.3975 \\
Years since planting $_{\text {Lagerstroemia spp. }}{ }^{\text {x }}$ & 0.5122 & 0.0831 & $<0.0001$ & 1.6689 & 1.4181 & 1.9640 \\
L. japonicum $^{\mathrm{x}}$ & -1.6871 & 0.5353 & 0.0016 & 0.1851 & 0.0648 & 0.5285 \\
\hline
\end{tabular}

×For species comparisons, Ilex $X$ attenuata 'Eagleston' was used as the baseline. For example, Lagerstroemia spp. were 0.19 times more likely to have a higher vitality rating when compared to the I. $X$ attenuate 'Eagleston' baseline.

Table B5. Final model and ordinal logistic regression results for conifer quality. Data was collected along Florida Department of Transportation corridors as part of a statewide "Bold Landscaping Initiative."

\begin{tabular}{|c|c|c|c|c|c|c|}
\hline Factor & Coefficient & SE & P-value & OR & CL low & CL high \\
\hline Irrigation - no & -2.0275 & 0.4393 & $<0.0001$ & 0.1317 & 0.0557 & 0.3115 \\
\hline Staked $>1$ year & 1.2161 & 0.4642 & 0.0088 & 3.3739 & 1.3583 & 8.3804 \\
\hline $\begin{array}{l}\text { Years since } \\
\text { planting }\end{array}$ & 1.1141 & 0.1708 & $<0.0001$ & 3.0467 & 2.1800 & 4.2581 \\
\hline INFRy & 0.7569 & 0.2232 & 0.0007 & 2.1316 & 1.3763 & 3.3016 \\
\hline P. palustris ${ }^{\mathrm{x}}$ & -3.8261 & 0.6478 & $<0.0001$ & 0.0218 & 0.0061 & 0.0776 \\
\hline T. distichum ${ }^{\mathrm{x}}$ & -2.8425 & 0.4522 & $<0.0001$ & 0.0583 & 0.0240 & 0.1414 \\
\hline
\end{tabular}

${ }^{x}$ For species comparisons, P. elliottii was used as the baseline. For example, P. palustris was 0.05 times more likely to have a higher quality rating when compared to the P. elliottii baseline. yRapid Urban Site Index factors within the model include distance to infrastructure (INFR). 
Table B6. Final model and ordinal logistic regression results for conifer vitality. Data was collected along Florida Department of Transportation corridors as part of a statewide "Bold Landscaping Initiative."

\begin{tabular}{lcccccc}
\hline Factor & Coefficient & SE & P-value & OR & CL low & CL high \\
\hline Irrigation - no & -3.1787 & 1.0567 & 0.0026 & 0.0416 & 0.0052 & 0.3303 \\
Staked >1 year & 2.8169 & 0.8545 & 0.0010 & 16.7252 & 3.1334 & 89.2748 \\
PPTy & -0.9136 & 0.2808 & 0.0011 & 0.4011 & 0.2313 & 0.6955 \\
P. palustris $^{\mathrm{x}}$ & -3.2312 & 0.9802 & 0.0010 & 0.0395 & 0.0058 & 0.2698 \\
${\text { T. } \text { distichum }^{\mathrm{x}}}$ & -2.3588 & 0.7508 & 0.0017 & 0.0945 & 0.0217 & 0.4118 \\
\hline
\end{tabular}

${ }^{x}$ For species comparisons, P. elliottii was used as the baseline. For example, P. palustris was 0.04 times more likely to have a higher vitality rating when compared to the P. elliottii baseline. yRapid Urban Site Index factors within the model include annual precipitation (PPT).

Table B7. Final model and ordinal logistic regression results for palm quality. Data was collected along Florida Department of Transportation corridors as part of a statewide "Bold Landscaping Initiative."

\begin{tabular}{lcccccc}
\hline Factor & Coefficient & SE & P-value & OR & CL low & CL high \\
\hline Berm - no & 0.5059 & 0.2321 & 0.0293 & 1.6584 & 1.0522 & 2.6139 \\
Season - wet & 1.0829 & 0.2077 & $<0.0001$ & 2.9533 & 1.9658 & 4.4368 \\
Staked > 1 year & 1.0503 & 0.2299 & $<0.0001$ & 2.8586 & 1.8215 & 4.4863 \\
Years since & -0.4642 & 0.1122 & $<0.0001$ & 0.6286 & 0.5045 & 0.7833 \\
planting & & & & & & \\
ECy & 0.5548 & 0.1647 & 0.0008 & 1.7416 & 1.2612 & 2.4050 \\
EXPy & -0.8154 & 0.1560 & $<0.0001$ & 0.4425 & 0.3259 & 0.6008 \\
GDDy & -0.2188 & 0.0943 & 0.0204 & 0.8035 & 0.6678 & 0.9666 \\
INFRy & 0.2637 & 0.0989 & 0.0077 & 1.3017 & 1.0724 & 1.5802 \\
SOMy & 0.2420 & 0.0865 & 0.0051 & 1.2738 & 1.0752 & 1.5091 \\
TXTy & -0.5982 & 0.2471 & 0.0155 & 0.5498 & 0.3388 & 0.8923 \\
A. alexandraex & 2.8005 & 0.6212 & $<0.0001$ & 16.4521 & 4.8691 & 55.5900 \\
B. nobilis & 4.6915 & 0.5041 & $<0.0001$ & 109.0165 & 40.5889 & 292.8040 \\
${\text { L. } \text { chinensis }^{\mathrm{x}}}_{\text {P. }}$ & 3.9869 & 0.5294 & $<0.0001$ & 53.8849 & 19.0917 & 152.0862 \\
R. regia $^{\mathrm{x}}$ & 4.3032 & 0.7648 & $<0.0001$ & 73.9360 & 16.5150 & 331.0054 \\
S. palmetto $^{\mathrm{x}}$ & 3.5801 & 0.5049 & $<0.0001$ & 35.8774 & 13.3359 & 96.5205 \\
W. robusta $^{\mathrm{x}}$ & 3.7465 & 0.4559 & $<0.0001$ & 42.3719 & 17.3375 & 103.5544 \\
\hline
\end{tabular}

xFor species comparisons, W. bifurcata was used as the baseline. For example, A. alexandrae was 16.5 times more likely to have a higher quality rating when compared to the W. bifurcata baseline. yRapid Urban Site Index factors within the model include electrical conductivity (EC), crownlight exposure (EXP), growing degree days (GDD), distance to infrastructure (INFR), soil organic matter (SOM), and soil texture (TXT) 


\section{References}

1. Ko, Y.; Lee, J.-H.; McPherson, E.G.; Roman, L.A. Factors affecting long-term mortality of residential shade trees: evidence from Sacramento, California. Urban For. Urban Green. 2015, 14, 500-507.

2. Koeser, A.K.; Gilman, E.F.; Paz, M.; Harchick, C. Factors influencing urban tree planting program growth and survival in Florida, United States. Urban For. Urban Green. 2014, 13, 655-661.

3. Leibowitz, R. Urban tree growth and longevity: an international meeting and research symposium white paper. Arboric. Urban For. 2012, 38, 237-241.

4. Lu, J.W.T.; Svendsen, E.S.; Campbell, L.K. Biological, social, and urban design factors affecting young street tree mortality in New York City. Cities Environ. 2010, 3, article 5.

5. Roman, L.A.; Scatena, F.N. Street tree survival rates: Meta-analysis of previous studies and application to a field survey in Philadelphia, PA, USA. Urban For. Urban Green. 2011, 10, 269-274.

6. Vogt, J.M.; Watkins, S.L.; Mincey, S.K.; Patterson, M.S.; Fischer, B.C. Explaining plantedtree survival and growth in urban neighborhoods: A social-ecological approach to studying recently-planted trees in Indianapolis. Landsc. Urban Plan. 2015, 136, 130-143.

7. McPherson, E.G. Monitoring Million Trees LA: Tree Performance During the Early Years and Future Benefits. Arboric. Urban For. 2014, 40, 285-300.

8. Widney, S.; Burnell, C.F.; Vogt, J. Tree mortality undercuts ability of tree-planting programs to provide benefits: results of a three-city study. Forests 2016, 7, 21.

9. NeSABitt, L.; Hotte, N.; Barron, S.; Cowan, J.; Sheppard, S.R.J. The social and economic value of cultural ecosystem services provided by urban forests in North America: A review and suggestions for future research. Urban For. Urban Green. 2017, 25, 103-111, doi:10.1016/j.ufug.2017.05.005.

10. Deng, J.; Arano, K.G.; Pierskalla, C.; McNeel, J. Linking Urban Forests and Urban Tourism: A Case of Savannah, Georgia. Tour. Anal. 2010, 15, 167-181, doi: $10.3727 / 108354210 X 12724863327641$.

11. Ko, Y. Trees and vegetation for residential energy conservation: A critical review for evidence-based urban greening in North America. Urban For. Urban Green. 2018, 34, 318-335, doi:10.1016/j.ufug.2018.07.021.

12. Berland, A.; Shiflett, S.A.; Shuster, W.D.; Garmestani, A.S.; Goddard, H.C.; Herrmann, D.L.; Hopton, M.E. The role of trees in urban stormwater management. Landsc. Urban Plan. 2017, 162, 167-177, doi:10.1016/j.landurbplan.2017.02.017.

13. Wolf, K.L. Freeway roadside management: the urban forest beyond the white line. $J$. Arboric. 2003, 29, 127-136.

14. Van Treese II, J.W.; Koeser, A.K.; Fitzpatrick, G.E.; Olexa, M.T.; Allen, E.J. A review of the impact of roadway vegetation on drivers' health and well-being and the risks associated with single-vehicle crashes. Arboric. J. 2017, 39, 179-193, doi:10.1080/03071375.2017.1374591.

15. McPherson, E.G.; Muchnik, J. Effects of street tree shade on asphalt concrete pavement performance. J. Arboric. 2005, 31, 303-310.

16. Miller, R.H.; Miller, R.W. Planting survival of selected street tree taxa. J. Arboric. 1991, 17, 185-191. 
17. Roman, L.A.; Battles, J.J.; McBride, J.R. The balance of planting and mortality in a street tree population. Urban Ecosyst. 2014, 17, 387-404, doi:10.1007/s11252-013-0320-5.

18. Petri, A.C.; Koeser, A.K.; Lovell, S.T.; Ingram, D. How green are trees? - Using life cycle assessment methods to assess net environmental benefits. J. Environ. Hortic. 2016, 34, 101-110.

19. Koeser, A.K.; Hauer, R.J.; Norris, K.; Krouse, R. Factors influencing long-term street tree survival in Milwaukee, WI, USA. Urban For. Urban Green. 2013, 12, 562-568.

20. Roman, L.A.; Battles, J.J.; McBride, J.R. Determinants of establishment survival for residential trees in Sacramento County, CA. Landsc. Urban Plan. 2014, 129, 22-31, doi:10.1016/j.landurbplan.2014.05.004.

21. Watson, W.T. Influence of tree size on transplant establishment and growth. HortTechnology 2005, 15, 118-122.

22. Ko, Y.; Lee, J.-H.; McPherson, E.G.; Roman, L.A. Long-term monitoring of Sacramento Shade program: Tree survival, growth, and energy saving performance. Landsc. Urban Plan. 2015, 143, 183-191, doi:doi.org/10.1016/j.landurbplan.2015.07.017.

23. Martin, M.P.; Simmons, C.; Ashton, M.S. Survival is not enough: The effects of microclimate on the growth and health of three common urban tree species in San Francisco, California. Urban For. Urban Green. 2016, 19, 1-6, doi:10.1016/j.ufug.2016.06.004.

24. van Doorn, N.S.; McPherson, E.G. Demographic trends in Claremont California's street tree population. Urban For. Urban Green. 2018, 29, 200-211, doi:10.1016/j.ufug.2017.11.018.

25. Nowak, D.J.; Kuroda, M.; Crane, D.E. Tree mortality rates and tree population projections in Baltimore, Maryland, USA. Urban For. Urban Green. 2004, 2, 139-147.

26. Jack-Scott, E.J. Survival and growth factors affecting community-planted urban street trees. Cities Environ. 2012, 4, Article 10.

27. Day, S.D.; Wiseman, P.E.; Dickison, S.B.; Harris, R.J. Tree Root Ecology in the Urban Environment and Implications for a Sustainable Rhizosphere. Arboric. Urban For. 2010, 36, 193-205.

28. Scharenbroch, B.; Catania, M. Soil quality attributes as indicators of urban tree performance. Arboric. Urban For. 2012, 38, 214-228.

29. Jim, C.Y. Massive tree-planting failures due to multiple soil problems. Arboric. J. 1993, 17, 309-331, doi:10.1080/03071375.1993.9746978.

30. Randrup, T.B.; McPherson, E.G.; Costello, L.R. A review of tree root conflicts with sidewalks, curbs, and roads. Urban Ecosyst. 2001, 5, 209-225.

31. McGrath, D.; Henry, J. Organic amendments decrease bulk density and improve tree establishment and growth in roadside plantings. Urban For. Urban Green. 2016, 20, 120 127, doi:10.1016/j.ufug.2016.08.015.

32. Jim, C.Y. Urban soil characteristics and limitations for landscape planting in Hong Kong. Landsc. Urban Plan. 1998, 40, 235-249, doi:10.1016/S0169-2046(97)00117-5.

33. Bary, A.; Hummel, R.L.; Cogger, C. Urban highway roadside soils and shrub-plantings enhanced by surface-applied and incorporated organic amendments. Arboric. Urban For. 2016, 42, 418-427.

34. Kristoffersen, P. Growing trees in road foundation materials. Arboric. J. 1999, 23, 57-76, doi:10.1080/03071375.1999.9747228. 
35. Jim, C.Y. Physical and chemical properties of a Hong Kong roadside soil in relation to urban tree growth. Urban Ecosyst. 1998, 2, 171-181, doi:https://link.springer.com/article/10.1023/A:1009585700191.

36. Morse, N.; Walter, M.T.; Osmond, D.; Hunt, W. Roadside soils show low plant available zinc and copper concentrations. Environ. Pollut. 2016, 209, 30-37, doi:10.1016/j.envpol.2015.11.011.

37. Harris, W.G.; Chrysostome, M.; Obreza, T.A.; Nair, V.D. Soil properties pertinent to horticulture in Florida. HortTechnology 2010, 20, 10-18.

38. Whitlow, T.H.; Bassuk, N. Trees in difficult sites. J. Arboric. 1987, 13, 10-17.

39. Roman, L.A.; Walker, L.A.; Martineau, C.M.; Muffly, D.J.; MacQueen, S.A.; Harris, W. Stewardship matters: Case studies in establishment success of urban trees. Urban For. Urban Green. 2015, 14, 1174-1182, doi:10.1016/j.ufug.2015.11.001.

40. Foster, R.S.; Blaine, J. Urban tree survival: trees in the sidewalk. J. Arboric. 1978, 4, 1417.

41. Roman, L.A.; McPherson, E.G.; Scharenbroch, B.C.; Bartens, J.A. Common practices and challenges for urban tree monitoring programs. Arboric. Urban For. 2013, 39, 292-299.

42. Allen, K.S.; Harper, R.W.; Bayer, A.; Brazee, N.J. A review of nursery production systems and their influence on urban tree survival. Urban For. Urban Green. 2017, 21, 183-191.

43. Koeser, A.K.; Stewart, J.R.; Bollero, G.A.; Bullock, D.G.; Struve, D.K. Impacts of Handling and Transport on the Growth and Survival of Balled-and-burlapped Trees. HortScience 2009, 44, 53-58.

44. Struve, D.K. Tree Establishment: A Review of Some of the Factors Affecting Transplant Survival and Establishment. Arboric. Urban For. 2009, 35.

45. Gilman, E.F.; Grabosky, J. Mulch and planting depth affect live oak (Quercus virginiana Mill.) establishment. J. Arboric. 2004, 30, 311-317.

46. Wells, C.; Townsend, K.; Caldwell, J.; Ham, D.; Smiley, E.T.; Sherwood, M. Effects of Planting Depth on Landscape Tree Survival and Girdling Root Formation. Arboric. Urban For. 2006, 32, 305-311.

47. Gilman, E.F.; Black, R.J.; Dehgan, B. Irrigation volume and frequency and tree size affect establishment rate. J. Arboric. 1998, 24, 1-9.

48. Gilman, E.F.; MieSABauer, J.; Harchick, C.; Beeson, R.C. Impact of tree size and container volume at planting, mulch, and irrigation on Acer rubrum L. growth and anchorage. Arboric. Urban For. 2013, 39, 173-181.

49. Labrosse, K.J.; Corry, R.C.; Zheng, Y. Effects of tree stabilization systems on tree health and implications for planting specifications. Arboric. Urban For. 2011, 37, 219-225.

50. Scharenbroch, B.C. A meta-analysis of studies published in Arboriculture \& Urban Forestry relating to organic materials and impacts on soil, tree, and environmental properties. $J$. Arboric. 2009, 35, 221.

51. Morgenroth, J.; Santos, B.; Cadwallader, B. Conflicts between landscape trees and lawn maintenance equipment - The first look at an urban epidemic. Urban For. Urban Green. 2015, 14, 1054-1058, doi:10.1016/j.ufug.2015.10.002.

52. Percival, G.C.; Smiley, E.T. The influence of stem girdling on survival and long term health of English oak (Quercus robur L.) and silver birch (Betula pendula Roth.). Urban For. Urban Green. 2015, 14, 991-999, doi:10.1016/j.ufug.2015.09.005.

53. Nowak, D.J.; McBride, J.R.; Beatty, R.A. Newly planted street tree growth and mortality. J. Arboric. 1990, 16, 124-129. 
54. Boyce, S. It Takes a Stewardship Village: Effect of Volunteer Tree Stewardship on Urban Street Tree Mortality Rates. Cities Environ. 2010, 3, 1-8, doi:10.15365/cate.3132010.

55. Limoges, S.; Pham, T.-T.-H.; Apparicio, P. Growing on the street: Multilevel correlates of street tree growth in Montreal. Urban For. Urban Green. 2018, 31, 15-25, doi:10.1016/j.ufug.2018.01.019.

56. Lima, J.M.T.; Staudhammer, C.L.; Brandeis, T.J.; Escobedo, F.J.; Zipperer, W. Temporal dynamics of a subtropical urban forest in San Juan, Puerto Rico, 2001-2010. Landsc. Urban Plan. 2013, 96-106.

57. Broschat, T.K. The effects of leaf removal on survival of transplanted sabal palms. $J$. Arboric. 1991, 17, 32-33.

58. Broschat, T.K. Effects of leaf removal, leaf tying, and overhead irrigation on pygmy date palms. J. Arboric. 1994, 20, 210-214.

59. Hodel, D.R.; Downer, J.; Pittenger, D.R. Effect of Leaf Removal and Tie-up on Transplanted Large Mexican Fan Palms (Washingtonia robusta). Palms 2006, 50, 76-81.

60. Broschat, T.K. Planting depth affects survival, root growth, and nutrient content of transplanted pygmy date palms. HortScience 1995, 30, 1031-1032.

61. Hodel, D.R.; Pittenger, D.R.; Downer, A.J. Palm root growth and implications for transplanting. J. Arboric. 2005, 31, 171-181.

62. Broschat, T.K. Root and shoot growth patterns in four palm species and their relationships with air and soil temperatures. HortTechnology 1998, 33, 995-998.

63. Hosek, L.-K.; Roloff, A. Species site matching: Selecting palms ( Arecaceae) for urban growing spaces. Urban For. Urban Green. 2016, 20, 113-119, doi:10.1016/j.ufug.2016.08.006.

64. Broschat, T.K.; Donselman, H. IBA, plant maturity, and regeneration of palm root systems. HortScience 1990, 25, 232.

65. Khatchatryan, H.; Hodges, A.W.; Rahmani, M.; Stevens, T.J. Economic Impacts of Highway Beautification in Florida; EDIS; Food and Resource Economics Department UF/IFAS Extension, 2014;

66. Mayer, H. Hurricane Irma and tree canopy loss: How did this happen? Fla. Arborist 2017, $20,36$.

67. Harrison, N.A.; Elliott, M.L. Texas Phoenix Palm Decline 2016.

68. Lugo, A.E.; Scatena, F.N. Background and Catastrophic Tree Mortality in Tropical Moist, Wet, and Rain Forests. Biotropica 1996, 28, 585, doi:10.2307/2389099.

69. Florida Grades and Standards for Nursery Plants; Florida Department of Agriculture \& Consumer Services: Gainesville, Florida, 2015;

70. Levinsson, A.; Fransson, A.-M.; Emilsson, T. Investigating the relationship between various measuring methods for determination of establishment success of urban trees. Urban For. Urban Green. 2017, 28, 21-27, doi:10.1016/j.ufug.2017.09.014.

71. Bond, J. Urban Tree Health: A Practical and Precise Estimation Method; Urban Forest Analytics: Geneva, NY, 2012;

72. Scharenbroch, B.; Carter, D.; Bialecki, M.; Fahey, R.; Scheberl, L.; Catania, M.; Roman, L.A.; Bassuk, N.; Harper, R.W.; Werner, L.; Siewert, A.; Miller, S.; Hutyra, L.; Raciti, S. A rapid urban site index for assessing the quality of street tree planting sites. Urban For. Urban Green. 2017, 27, 279-286, doi:10.1016/j.ufug.2017.08.017.

73. Misra, V.; Mishra, A. The oceanic influence on the rainy season of Peninsular Florida. $J$. Geophys. Res. Atmospheres 2016, 121, 7691-7709, doi:10.1002/2016JD024824. 
74. R Core Team R: A Language and Environment for Statistical Computing; R Foundation for Statistical Computing: Vienna, Austria, 2016;

75. Holm, S. A Simple Sequentially Rejective Multiple Test Procedure. Scand. J. Stat. 1979, 6, 65-70.

76. Venables, W.N.; Ripley, B.D. Modern applied statistics with S; Statistics and computing; 4th ed.; Springer: New York, 2002; ISABN 978-0-387-95457-8.

77. Crawley, M.J. The R book; Second edition.; Wiley: Chichester, West Sussex, United Kingdom, 2013; ISABN 978-0-470-97392-9.

78. Gilman, E.F. Effects of amendmendts, soil additives, and irrigation on tree survival and growth. J. Arboric. 2004, 30, 301-310.

79. Putterman, S. June's heavy rains wash away Florida's severe drought. Tampa Bay Times 2017.

80. Broschat, T.K. Palm Nutrition and Fertilization. HortTechnology 2009, 19, 690-694.

81. Sanders, J.R.; Grabosky, J.C. 20 years later: Does reduced soil area change overall tree growth? Urban For. Urban Green. 2014, 13, 295-303, doi:10.1016/j.ufug.2013.12.006.

82. Broschat, T.K.; Meerow, A.W.; Elliott, M.L. Ornamental palm horticulture; Second edition.; University Press of Florida: Gainesville, FL, 2000; ISABN 978-0-8130-6227-3. 